\title{
Planktonic and Benthic Foraminifera Miocene on Sandstone Unit of Bentang Formation in Pangandaran, West Java
}

\author{
Lilian C. Rieuwpassa ${ }^{1 *}$, Gabriela C. N. Gaspersz ${ }^{2}$, Vijaya \\ Isnaniawardhani ${ }^{2}$ and Santi Dwi Pratiwi ${ }^{2}$ \\ ${ }^{1}$ Undergraduate Program of Geological Engineering, Universitas Padjadjaran, Bandung, Indonesia \\ ${ }^{2}$ Department of Geoscience, Faculty of Geological Engineering, Universitas Padjadjaran, Bandung Jalan Raya Bandung- \\ Sumedang Km.21 Jatinangor, Kab. Sumedang 45363, Jawa Barat, Indonesia
}

\begin{abstract}
The research in Pangandaran was due to the presence of exposed rock lithology and the presence of fossil content, either macrofossil or microfossil. Research sites are located at $108^{\circ} 27^{\prime} 46.55^{\prime \prime}$ to $108^{\circ} 30^{\prime} 29.88^{\prime \prime} \mathrm{E}$ and $7^{\circ} 41^{\prime} 35.54^{\prime \prime}$ to $6^{\circ} 38^{\prime} 53.60^{\prime \prime}$. This study was conducted to determine the distribution of foraminifera contained in the constituent sandstone units of the Bentang Formation. The research was conducted at 7 (seven) points of location of sandstone outcrops. Analysis and identification of foraminifera using a binocular microscope after foraminifera preparation. The distribution areas of the sandstone units of the study area are in the Cimanggu, Bula Krandu and Karangbenda areas. Age datum markers that are characterized by planktonic foraminifera fossils, namely Sphaerodinellopsis multilobe and Globigerinoides ruber. Benthic foraminifera dominated by Lenticulina suborbicularis, Nouvigerina ampulaceae, Cibicides tenuimargo, Anomalinoides globulosus, Heterolepa praecincta, Ammonia convexa reflects a shallow marine bathymetry zone or mid neritic $(50-100 \mathrm{~m})$. Based on the content of planktonic and bentonic foraminifera, the sandstone units of the Bentang Formation were deposited during the Middle Miocene (N12-N13) age in a shallow marine depositional environment.
\end{abstract}

Keywords: Foraminifera, Sandstone Unit, Bentang Formation, Pangandaran

\section{Introduction}

Marine sediments can reconstruct paleoecological parameters such as sea surface temperature, water chemical composition, biomass information, variations in geomagnetic areas, sea level, precipitation, and solar activity, by utilizing proxies contained therein (Meissner, 2007; Bradley, 2015).

Foraminifera is a single celled microorganism or protist that has a shell with its life strongly influenced by various environmental factors so that it can be used as an indicator of environmental change and is a potential proxy for paleoecological, paleoclimatological and paleoseanographic research (Pringgoprawir, 1984; Saraswat, 2015).

Foraminifera consists of benthic foraminifera and planktonic foraminifera. Benthic foraminifera can be found in abundance in sediment deposits and have properties that greatly affect the environment in which they live, such as brightness, $\mathrm{pH}$, turbidity, salinity, oxygen levels and depth (Boltovskoy and Wright, 1976; Gustiani et al, 2015), so that they can determine the environment of deposition. Meanwhile, planktonic foraminifera has a small number of general but has a very large number of species by way of life floating on the surface and is widespread so that when planktonic foraminifera die, it will be deposited and spread widely so that it can determine its age.

Based on the geographical location and regional geology, the location of the study area is included in the Middle Miocene to Early Pliocene age range with a shallow to open ocean depositional environment with a thickness of approximately 300 meters (Supriatna, et al, 1992). The Bentang Formation is composed lithology of limestone sandstone lithology, tuff sandstones, shale inserts and limestone lenses. 


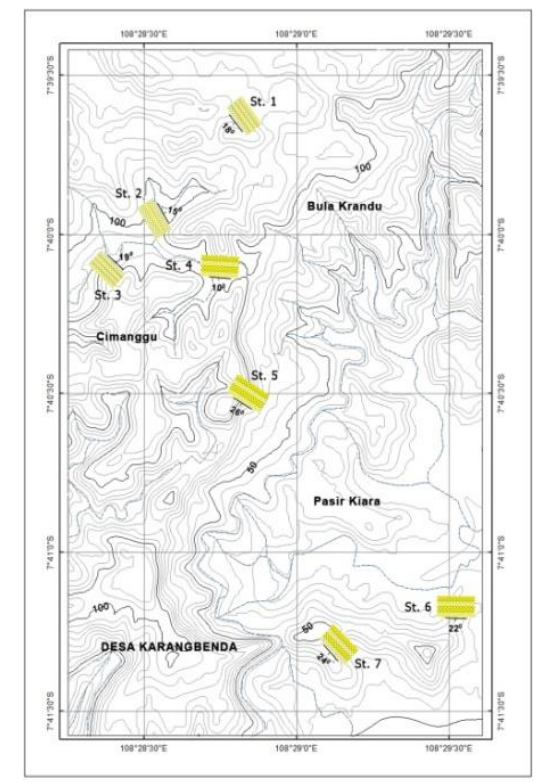

Fig. 1. Map of the Research Area

The Pangandaran area is used as a research area with all scattered rock lithology due to the influence of endogenous and exogenous processes as well as the presence of fossil content, either macrofossil or microfossil. In addition, the area has a very interesting landscape to serve as an object in other geological sciences.

This research was conducted to identify the distribution of foraminifera and interpretation the age and depositional environment of sandstone units in the Bentang Formation.

\section{Methodology}

This study used qualitative data collection techniques consisting of literature reviews, field observations and laboratory analysis. Field data collection was carried out directly or spoting at seven station points in the research area including descriptions of outcrops, sampling and photos. This research was conducted in Cimanggu village, Bula Krandu village, Pasir Kiara village and Karangbenda village (Fig. 1).

Further sediment sample analysis begins with a preparation process which consists of several stages, including washing the sample, picking, describing and identifying and documenting. Foraminifera uses the current preparation technique by taking \pm 100 - 300 grams of dry sediment and crushing the sample using a porcelain collision until it is slightly smooth. Then, put it in a bowl and dissolve it with about $10-15 \% \mathrm{H}_{2} \mathrm{O}_{2}$ to separate the microfossil from the rock matrix. Let stand for one day until no reaction occurs. After there is no reaction, prepare a 30-80-100 mesh sieve and wash all residue with heavy water with a filter size of 30-80-100 mesh. At 80-100 mesh, the remaining residue is taken and then dried in an oven $\pm 600^{\circ} \mathrm{C}$ for one day. After drying, the residue is packed in plastic and labeled with a sample code.

The next stage is continued with the process of description and identification of foraminifera specimens and classified based on shell morphology, including shell shape, room shape, room formation, number of rooms, shell ornamentation, slope of the apertura, position of the apertura and additional chambers referring to Bolli's classification (1985).

The research phase lasts for two weeks starting from March 2, 2020 to March 16, 2020. 


\section{Results and Discussion}

Megascopically, the lithology of the sandstones have the characteristics of a fresh white dark gray color and weathered gray brownish color. Has a grains size of medium sand (1/2-1/4 mm) to very fine sand (1/8-1/16 $\mathrm{mm}$ ), grain shape subrounded to rounded grain shape, closed packing, fine sorting, carbonate and hard hardness. This sandstone outcrop is clearly visible showing the presence of a sedimentary structure, namely bedding (Fig. 2).

The distribution areas of the sandstone units in the study area are in the village of Cimanggu, Bula Krandu, Pasir Kiara and Karangbenda. The measurement results of the direction of the layer and the slope of the sandstone in general show the direction of the layer in a relatively southwest-southeast direction and the slope of the layer from $10^{\circ}$ to $24^{\circ}$. The research area shows that the geological structure that develops is the fold. Based on geographic location, these sandstones are part of the Bentang Formation.

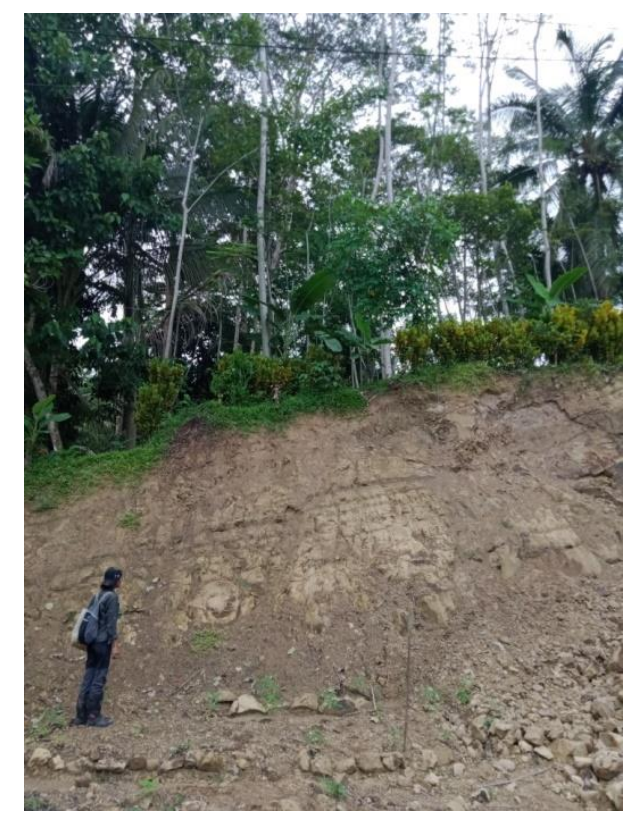

Fig. 2. Bedding Sandstone Outcrops

By microscopic, thin section of very fine sandstones is composed of a percentage of matrix $60 \%$ and fragments $40 \%$ which consists of a collection of minerals K-Feldspar $20 \%$, calcite $5 \%$, quartz 5\%, opaque minerals $5 \%$, and fossil fragments $10 \%$ (Fig. 3). There are large foraminifera and algae which are already filled with a matrix of rocks. There is a slight brownish ooid, rounded shape, high relief, and weak pleochroism and blackish gray peloid, oval shape, high relief, weak pleochroism. Based on the classification (Pettijohn, 1975), this rock is included in the Feldsphatic Greywacke (Tandean, 2019). 


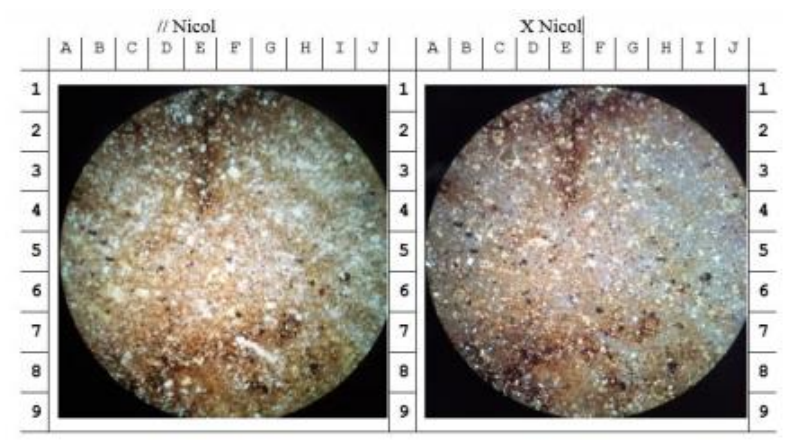

Fig. 3. Thin Section of Sandstone

(Source; Tandean, 2019)

\section{Planktonic Foraminifera}

Based on the analysis of foraminifera at sandstone samples that found of foraminifera planktonic is Globigerinoides ruber and Sphaerodinellopsis multilobe, it can be interpreted that the relative age range of these sandstone units is N12 to N13 or Middle Miocene.

\section{Globigerinoides ruber}

The Globigerinoides ruber (Fig. 4) has a low trochospiral shell, biconvex. The composition of the limestone wall, rough porous, mottled surface. The shell is very thick, composed of two loops, the three chambers at the last turn enlarge slowly but clearly separate. The umbilicus is narrow. The primary interiomarginal aperture, umbilical, bordered by the lip, secondary sutural aperture in reverse position in the initial chamber. Age range N5 to N13.

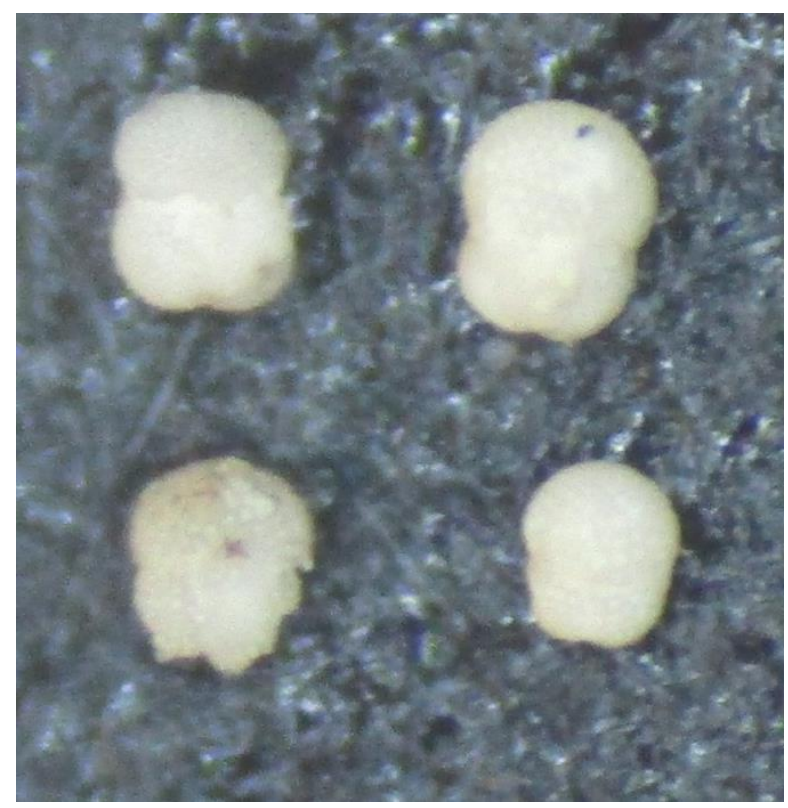

Fig. 4. Globigerinoides ruber 


\section{Sphaerodinellopsis multilobe}

Sphaerodinellopsis multilobe (Fig. 5) has regularly enlarged, subglobular, or subreniform spaces, or shows a tendency to elongate radially in adults, or to embrace. Primary interiomarginal, intraumbilical aperture, low arch or fissure, complemented by smooth or curved lips. There are no additional holes. Age range N12 to N16.

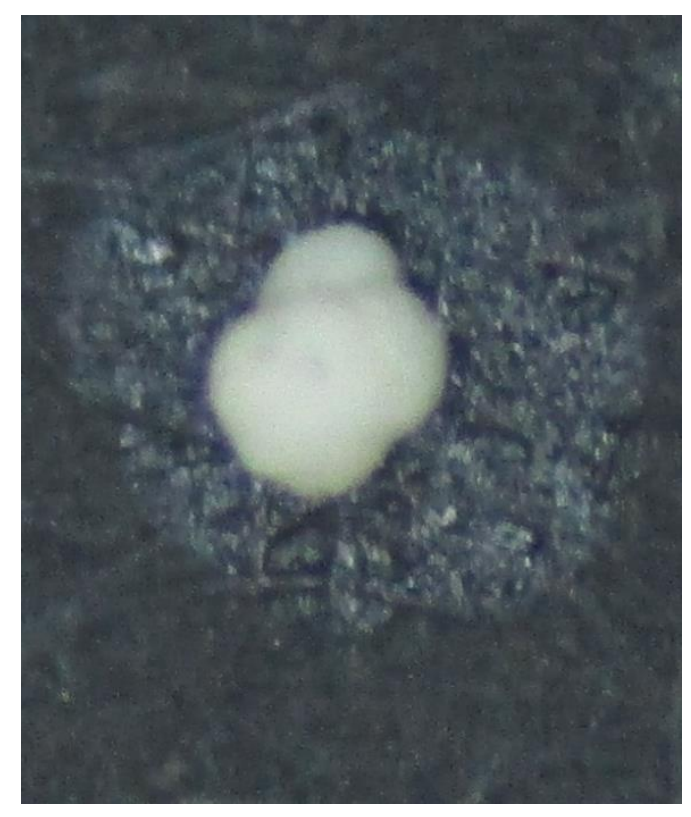

Fig. 5. Sphaerodinellopsis multilobe

\section{Benthic Foraminifera}

Benthic foraminifera found in sandstone units consist of Lenticulina suborbicularis, Nouvigerina ampulaceae, Cibicides tenuimargo, Anomalinoides globulosus, Heterolepa praecincta and Ammonia convexa. The benthic foraminifera fossils found can be interpreted as being deposited in a shallow marine environment, namely the middle neritic with a depth 50 to 100 meters.

\section{Lenticulina suborbicularis}

Lenticulina suborbicularis has a shell shaped, biconvex, symmetrical on both sides, angled periphery and is equipped with a thin kell, composed of rooms arranged in involut planispiral, round slightly closed; suture protruding, curving; slit-shaped aperture is located peripherally with radiate trimmings (Fig. 6). Lenticulina suborbicularis has a depth of about 88.39 meters and the bathymetric zone belongs to the middle neritic (50 to 100 meters). 


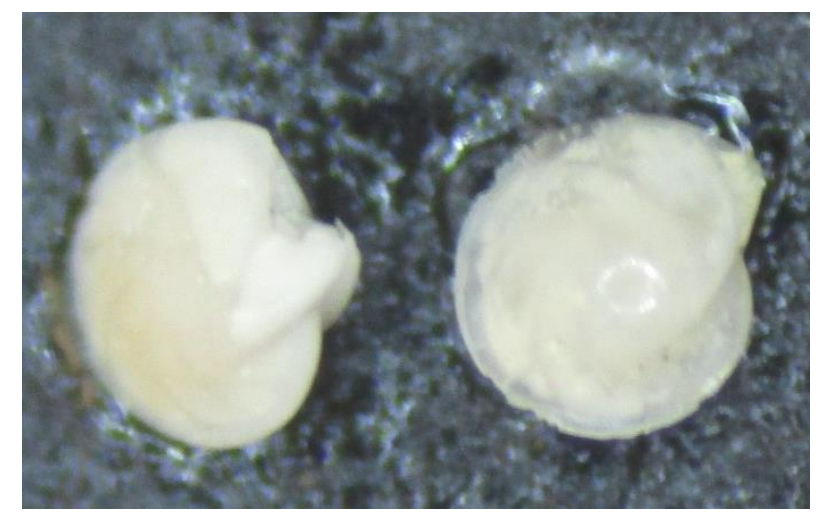

Fig. 6. Lenticulina suborbicularis

\section{Nouvigerina ampulaceae}

Nouvigerina ampulaceae has a polythalamus shell, the composition of the shell wall is agglutinins. Oval round shell, expanding chambers arranged in a rotated trident, fast enlargement; decoration in the form of high branches, continuous from the previous round room to the next round room, not interrupted by sutures; terminal aperture, short neck, surrounded by lips (Fig. 7). Neouvigerina ampulaceae has a depth of about 91.40 meters and belongs to the middle neritic bathymetry zone (50 to 100 meters).

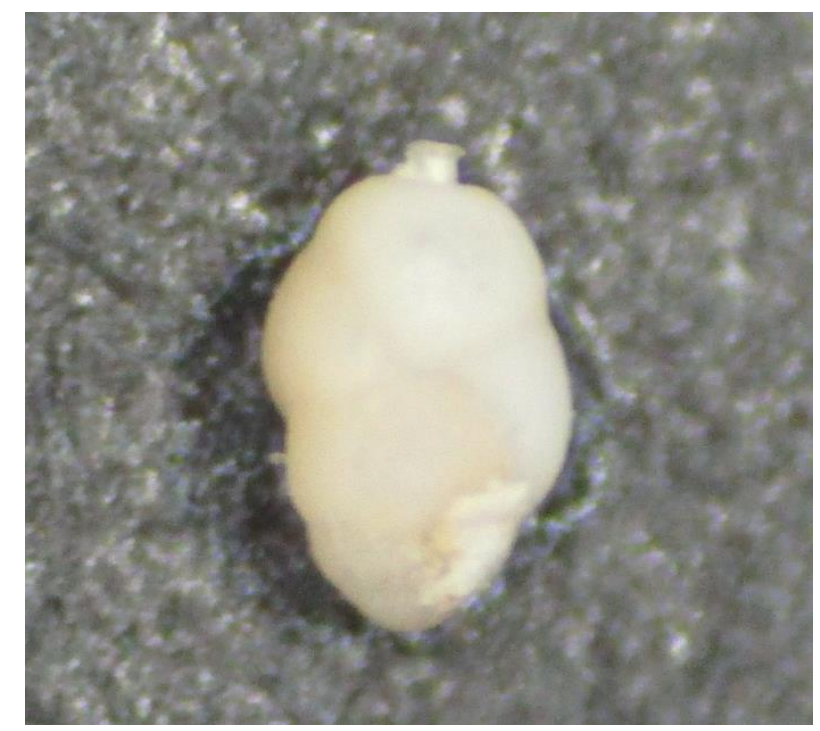

Fig. 7. Nouvigerina ampulaceae

\section{Cibicides tenuimargo}

Cibicides tenuimargo have planispiral, uniformed, rotated uniserial shells evolute (Fig. 8). Planoconvex shell, arrangement of polythalamic chambers. Composition of the walls of the calcareous shell. Aperture in the interiomarginal position. The sutura are not clearly visible. Cibicides tenuimargo has a depth of about 93.27 meters in the middle neritic bathymetry zone (50 to 100 meters). 


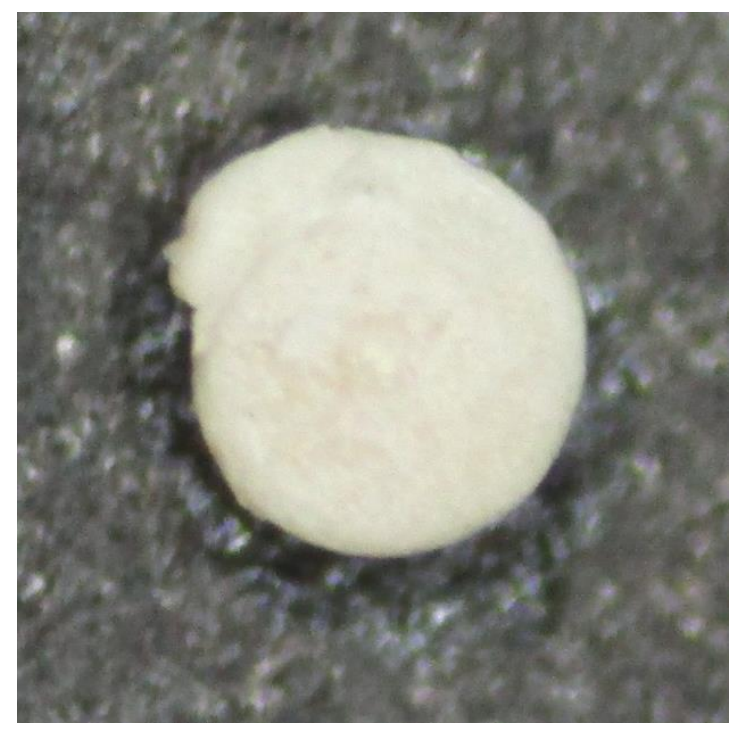

Fig. 8. Cibicides tenuimargo

\section{Anomalinoides globulosus}

Anomalinoides globulosus (Fig. 9) has a strong, trochospiral, planoconvex shell with very convex sides. Involute on the umbilical side and evolut on the spiral side. Wide rounded edges. There are 5-10 rooms that inflate in the last round. The sutures are depressed, wavy on the spiral side and almost straight on the umbilical side. Aparture in the form of a sabir facing the edge of the rotation. Anomalinoides globulosus has a depth of about 71.63 meters and is included in the middle neritic bathymetry zone (50 to 100 meters).

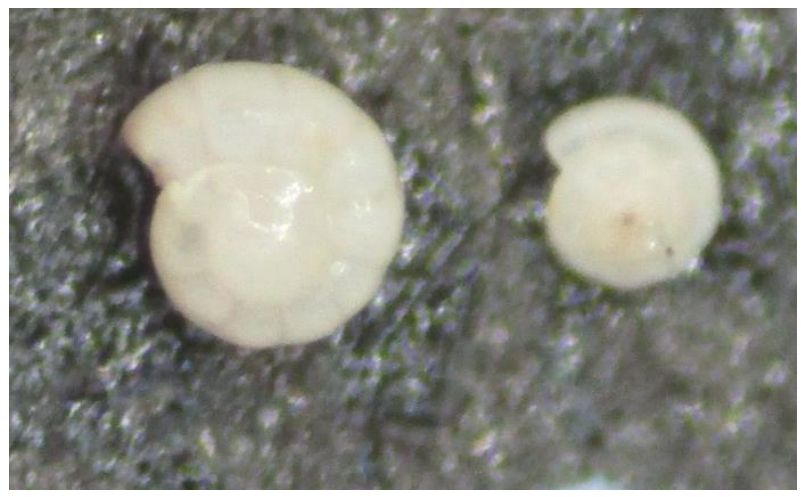

Fig. 9. Anomalinoides globulosus

\section{Heterolepa praecincta}

Heterolepa praecincta (Fig. 10) has a polythalamus shell. Composition of the walls of the calcareouse hyaline shell, trochospiral. The shell is shaped like a bowl, rooms composed of three rounds, eleven chambers at the last turn, enlarging slowly; suture slightly reclining towards the back, interomarginal aperture, extraumbilicalumbilical, silt-like and smooth ornamentation. Heterolepa praecincta has a depth of about 60.96 meters with a bathymetric zone including the middle neritic (50 to 100 meters). 


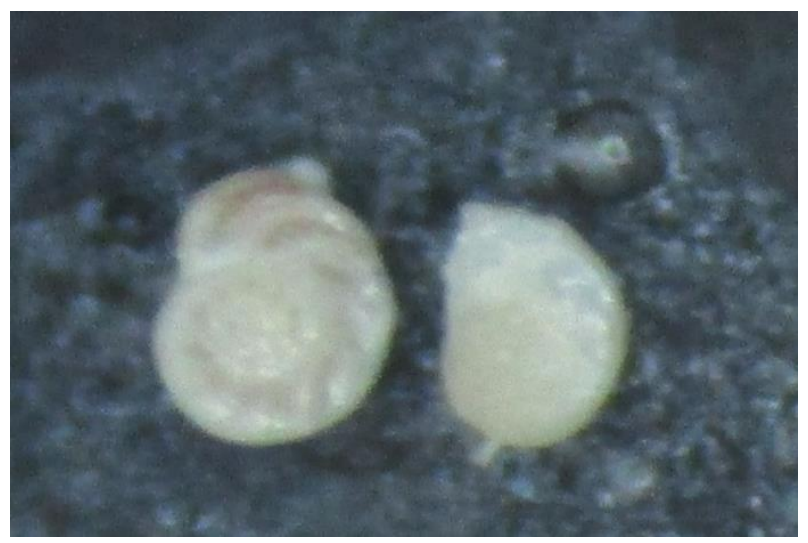

Fig. 10. Heterolepa praecincta

\section{Ammonia convexa}

Ammonia convexa (Fig. 11) has a trochospiral shell, uniformed, uniserial rotated evolute. The periphery is rounded. Polythalamus chamber arrangement. Composition of the wall of the calcareous hyaline shell. Interiomarginal aperture to the umbilicus. The suture is flat and not very clear. Ammonia convexa has a depth of about 62.48 meters with a middle neritic bathymetry zone (50 to 100 meters).

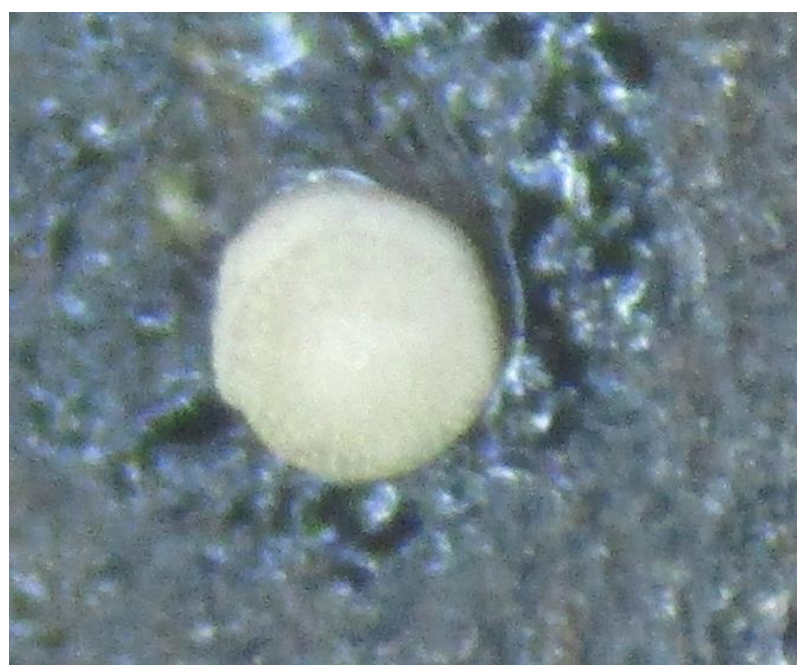

Fig. 11. Ammonia convexa

The results of the identification of planktonic and benthic foraminifera content in the Bentang Formation show that benthic foraminifera live at a depth of 50 to 100 meters or middle neritic with sea water temperature that is influenced by the penetrating power of the sun or the photic zone with a level of salinity of normal sea water or sea water $<30-39 \%$, the same of planktonic foraminifera which generally live and develop in normal sea water.

\section{Conclusion}

The distribution of sandstone units in the research area is in Cimanggu, Bula Krandu, Pasir Kiara and Karangbenda village. Characteristics of grain size of sandstones range from medium grain size (1/2-1/4 mm) to very fine sand (1/8-1/16 mm). The sandstone outcrop shows bedding in the direction of the layer direction in a relatively southwest-southeast direction and the study area is influenced by fold. 
The presence of planktonic foraminifera Globigerinoides ruber and Sphaerodinellopsis multilobe which is used to characterize the age of the sandstone units in the Bentang Formation, it can be determined that the age range of sandstone units is N12 to N13 or Middle Miocene.

Based on the benthic foraminifera fossils Lenticulina suborbicularis, Nouvigerina ampulaceae, Cibicides tenuimargo, Anomalinoides globulosus, Heterolepa praecincta and Ammonia convexa, it is interpreted that the sandstone units are deposited of shallow marine environment in the middle neritic with a depth 50 to 100 meters.

\section{Recommendation}

The results of the analysis of the distribution of foraminifera in the Sandstone Unit of the Bentang Formation, in this study, are expected to be of benefit to the research area. However, this study still wants to be complemented by further research that can discuss micropaleontological studies in the research area.

\section{Acknowledgements}

The authors would like to thank to Dean of the Faculty of Geological Enginerring Univeristas Padjadjaran for financial support and also like to co-author and colleagues of Geological Engineering Faculty during this research process.

\section{References}

Dunham RJ (1962) Classification of Carbonate Rocks According to Depositional Texture. In: Classification of Carbonate Rocks (Ed. W. E. Ham), Am. Assoc. Pet. Geol. Mem., 1, 108-121

Bradley RS (2015) Paleoclimatology: Reconstruction Climates of The Quaternary, Third Edit. Ed. Elsevier, Oxford

Bolli HM and Saunders JB (1985) Planktonic Stratigraphy. Cambridge : Cambridge Universty Press

Boltovskoy E and Wright R (1976) Recent Foraminifera

Blow WH (1969) Late Middle Eocene to Recent Planktonic Foraminifera Biostratigraphy Cont. Planktonic Microfossil, Geneva, 1967, Pro. Leiden, E.J Bull v

Gustiantini L et al (2015) Foraminiferal Distribution Since The Last Glacial Until Recent In Halmahera Sea. J. Geol. Kelaut. 13, 25-36

Meissner KJ (2007) Proxies in Late Cenozoic Paleoceanography. Development in Marine Geology. https://doi.org/10.1016/S1572-5480(07)01025-1

Pringgopawiro H (1984) Dictate of Advanced Micropaleontology, Laboratory of Micropaleontology, Department of Geological Engineering, ITB, Bandung.

Saraswat R (2015) Non-destructive foraminiferal paleoclimate proxies: A brief insight. Proc. Indian Natl. Sci. Acad. 81, 381-395.https://doi.org/10.16943/ptinsa/2015/v*li2/48094

Supriatna S et al (1992) Geological Map Of The Karangnunggal, Jawa. Research and Development Centre Geology: Bandung

Tandean IN (2019) Parakanmanggu Regional Geology, Parigi District, Ciamis Regency, Jawa West Province. Faculty of Geological Engineering, Universitas Padjadjaran. 